\title{
Dynamics of the planktonic food web in Colgada Lake (Lagunas de Ruidera Natural Park)
}

\author{
Carmen Rojo *, María A. Rodrigo and M. Mercedes Barón-Rodríguez
}

Grupo de Ecología Integrativa. Instituto Cavanilles de Biodiversidad y Biología Evolutiva, Universidad de Valencia. Apartado Oficial 22085, 46071, Valencia.

* Corresponding author: carmen.rojo@uv.es

\begin{abstract}
Dynamics of the planktonic food web in Colgada Lake (Lagunas de Ruidera Natural Park)

In Colgada Lake, one of the 15 lakes belonging to Lagunas de Ruidera Natural Park, the components of the lineal food chain (phytoplankton and metazooplankton) and the microbial loop phytoplankton, metazooplankton, ciliates, autotrophic picoplankton, and bacterioplankton) were studied from June 2003 to December 2004 with a monthly sampling frequency. This lake has monomictic and mesotrophic characteristics and a mean depth of $8 \mathrm{~m}$. Sixty-two species of the phytoplankton community, 27 species of metazooplankton community, and 12 species of ciliates were identified. Phytoplankton and metazooplankton integrated biomass followed seasonal patterns with higher values in summer, up to $10^{5} \mathrm{mg} \mathrm{WW} / \mathrm{m}^{2}$ and $2 \times 10^{4} \mathrm{mg} \mathrm{WW} / \mathrm{m}^{2}$, respectively. Autotrophic picoplankton did not exceed $500 \mathrm{mg} \mathrm{WW} / \mathrm{m}^{2}$. Microbial loop components did not show seasonality, and its biomass concentration fluctuated between $500-2500 \mathrm{mg} \mathrm{WW} / \mathrm{m}^{2}$ for ciliates and 100 $2000 \mathrm{mg} \mathrm{WW} / \mathrm{m}^{2}$ for bacterioplankton. Centric Bacillariophyceae, Cryptophyceae, and Dinophyceae represented most of the phytoplanktonic biomass throughout the studied period, although an increase of cyanobacteria was also observed. Cladocerans and calanoid copepods dominated during summer stratification, rotifers and cyclopoid copepods were present during the winter mixing period. The microbial loop biomass in relation to total planktonic biomass was higher in winter and spring 2004. Interannual changes in the presence of planktonic groups were observed in the different periods of the year: i) the algal composition included larger and non-edible species (Cyanobacteria, Dinophyceae), ii) a reduction in the clearance function by cladocerans was produced, which were substituted by a cyclopoid predator that iii) can feed on rotifers and ciliates, favouring in this way bacterioplankton and autotrophic pico-nanoplankton. This interannual variation could be related to the ongoing eutrophication process in the Lake. All of this may change the way the lake looks: if spring primary production is not strongly controlled by herbivory, this could threaten the annual recruitment of submerged macrophytes that significantly contribute to improve the water quality of the lake.
\end{abstract}

Key words: Phytoplankton, bacterioplankton, autotrophic picoplankton, ciliates, rotifers, copepods, cladocerans, eutrophication.

\section{RESUMEN}

Dinámica de la red trófica planctónica en la laguna Colgada (Parque Natural de las Lagunas de Ruidera)

En la laguna Colgada, una de las 15 lagunas que componen el Parque Natural de Las lagunas de Ruidera, se han estudiado los componentes de la red trófica planctónica (fitoplancton, metazooplancton, ciliados, picoplancton autotrófico -PPA- y bacterioplancton), desde junio de 2003 a diciembre de 2004, con una frecuencia de muestreo mensual. Esta laguna posee un carácter monomíctico y mesotrófico y una profundidad media de $8 \mathrm{~m}$. Se identificaron 62 especies de la comunidad fitoplanctónica, 27 especies de la comunidad de metazooplancton y 12 especies de ciliados. La biomasa integrada de fitoplancton y metazooplancton mostró un patrón estacional con valores más elevados en verano, hasta $10^{5} \mathrm{mg} P F / \mathrm{m}^{2}$ y

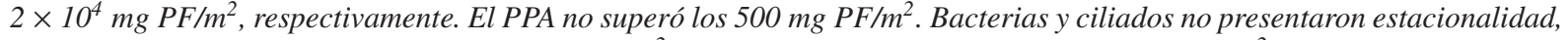
y su concentración fluctuó entre 500-2500 mg PF/ $\mathrm{m}^{2}$ en el caso de los ciliados y 100-2000 mg PF/ $\mathrm{m}^{2}$ en el bacterioplancton. Poblaciones de Bacillariophyceae de tipo centrales, Cryptophyceae y Dinophyceae constituyeron la mayor parte de la biomasa fitoplanctónica durante todo el periodo de estudio, aunque se observó un incremento de cianobacterias. Cladóceros y copépodos calanoides fueron dominantes durante la estratificación estival, rotíferos y copépodos ciclopoides estaban presentes en la mezcla invernal. La biomasa relativa del bucle microbiano frente al total de biomasa planctónica fue superior en inverno y primavera de 2004. Se han observado cambios interanuales en la presencia de los grupos planctónicos de 
los diferentes periodos del año: i) la composición algal incluye especies más grandes y menos comestibles (Cyanobacteria, Dinophyceae), ii) se produce una reducción de la función de aclarado de los cladóceros que son sustituidos por un depredador ciclopoide que iii) se pue de alimentar de rotíferos y ciliados, favoreciendo así a las bacterias y el pico-nanoplancton autotrófico. Esta variación interanual podría estar relacionada con el proceso de eutrofización que está sufriendo la laguna. Todo ello puede llegar a cambiar el aspecto de la laguna: si la producción primaria en primavera no está fuertemente controlada por la herbivoría, se puede impedir el reclutamiento anual de los macrófitos sumergidos que contribuyen significativamente a mejorar la calidad de la aguas de esta laguna.

Palabras clave: Fitoplancton, bacterioplancton, picoplancton autotrófico, ciliados, rotíferos, copépodos, cladóceros, eutrofización.

\section{INTRODUCTION}

The temporal variability of patterns observed in aquatic communities can provide a good source of information on the processes affecting them (Huber \& Gaedke, 2006). A good understanding of such processes is essential to anticipate the effect of several anthropogenic disturbances undergone by aquatic ecosystems (Håkanson \& Peters, 1995). Plankton is an important component of the aquatic community and the study of planktonic dynamics is relevant if temporal changes caused by anthropic factors such as eutrophication are to be observed (Rojo 1998; Reynolds et al., 2000; Sommer et al., 2002). The phytoplankton, zooplankton, and the components of the microbial loop will respond to these variations, and changes may be observed not only in the trophic structure of the plankton itself but also in its production.

The detected changes in phytoplankton composition indicate the trend in the water quality, (Reynolds, 1998) but they can also indicate the establishment of new trophic relationships (Carpenter et al., 2001) and, consequently, of being the cause of severe alterations in lakes, such as the sudden loss of the necessary light for the growth of macrophytes at bottom levels (Scheffer et al., 1993). The presence of one or more groups of zooplankters is an indicator of water quality but, moreover, the seasonal dynamics and the changes or substitution of key populations by others (Ortega-Mayagoitia et al., 2000; Sommer $\&$ Sommer, 2006) will also shape a new lake pa- norama (Cottingham, 1999) affecting non planktonic species (submerged macrophytes, planktivorous fishes, ducks etc). Finally, the dynamics of the components (heterotrophic bacteria and protists) of the microbial loop (Pomeroy, 1974; Azam et al., 1983) are sensitive to the alterations suffered by aquatic ecosystems. Studying these changes relevant to the food web provide information on the nutrient flux changes (JoaquimJusto et al., 2006; Niquil et al., 2006) and its own planktonic composition (Muylaert et al., 2006).

For several decades planktonic production has been related to eutrophication (OECD, 1982). In the same way, community trophic structure has been related to the efficiency of matter and energy transfer (Kitchell \& Carpenter, 1993). From the second point of view, several studies have demonstrated that in a large number of aquatic ecosystems, the populations involved in the microbial loop may be responsible for a large part of the carbon and energy production in the pelagic, when compared to the transfer observed in lineal food webs formed by phytoplankton and metazooplankton (Weisse et al., 1990). However, this microbial fraction has either been considered infrequent or underestimated due for instance to observation and enumeration difficulties, and in the case of ciliates, because of problems of identification (de Eyto \& Irvine, 2005). Bacteria have been considered to play an important role in the matter and energy flux through food webs, since, firstly, they may re-mineralise the particulate and dissolved organic matter by releasing inorganic nutrients that can be 
assimilated by phytoplankton. Secondly, bacteria transform dissolved organic matter in biomass and constitute a direct source of energy and carbon for higher trophic levels (Elser et al., 1995). The main consumers of bacteria are protists, such as the heterotrophic nanoflagellates and the ciliates, but metazooplankters, such as rotifers and cladocerans can feed on bacteria as well. Due to their size, autotrophic picoplankton (composed by prokaryotes, such as coccal Cyanobacteria, and eukaryotes; Stockner, 1991), may be a food source for the same trophic levels as the bacterioplankton (Sherr et al., 1991). Ciliates, efficient consumers of bacteria, autotrophic picoplankton and other small algae (Cleven, 2004; de Eyto \& Irvine, 2005), can channel up this production to higher trophic levels, since the metazooplankton can predate on these organisms. (Sherr \& Sherr, 2002). A classic model of plankton dynamics ("PEG model", Plankton Ecology Group by Sommer et al., 1986) could be made more explicit, or even modified with respect to predictions when considering the microbial loop (Jeppesen et al., 1996) and the processes affecting the lake, such as eutrophication or its particular hydrology (Álvarez-Cobelas et al., 2006a and b).

The studies that integrate the different planktonic fractions are useful for water quality control (Water Framework Directive, European Community), but also for helping in the understanding of lake functioning and the prediction of its future in highly endangered ecosystems such as those in Spain. This work is a part of an interdisciplinary study which tackles the fate of nitrogen, since recently one of the main pollutants of continental waters (Vitousek et al., 1997), in Lagunas de Ruidera Natural Park (Albacete-Ciudad Real). Of the 15 interconnected lakes, Colgada Lake, is the most studied. The lake is fed mainly by subterranean waters with a high nitrogen level (Álvarez-Cobelas et al., 2006b). This lake, together with many other small La Mancha lakes from La Mancha, was previously studied by Armengol et al. (1975). The plankton of the Ruidera Lakes (including Colgada Lake) was described (Bort et al., 2005; Álvarez-Cobelas et al., 2006a) in a seasonal study of the epilimnion las- ting two consecutive years (2000-2001). Rodrigo et al. (2003) compared the picoplankton (autotrophic and heterotrophic) of these lakes with that of some Spanish wetlands.

The objectives of this work are to contribute to planktonic food web knowledge, including the main components of the microbial loop, and to describe the plankton dynamics in order to finally relate the observed changes in the planktonic trophic structure to the environmental variations registered in Colgada Lake, due to the trophic level increase.

\section{MATERIAL AND METHODS}

\section{Study site}

Colgada Lake is part of the 15 chain-connected lakes belonging to Lagunas de Ruidera Natural Park $\left(40^{\circ} 55^{\prime} \mathrm{N}, 5^{\circ} 40^{\prime} \mathrm{W}\right)$, located between Albacete and Ciudad Real (Castilla-La Mancha, Spain). The lake has a surface of 100 ha, a mean depth of $8 \mathrm{~m}$ and a maximum depth of $18 \mathrm{~m}$. It is monomictic and thermally stratifies during the warm season and mixes with the arrival of autumn. Colgada Lake is mesotrophic, since the mean annual chlorophyll $a$ concentrations range from 0.8 to $7.3 \mu \mathrm{g} / \mathrm{l}$. Mean annual total phosphorus concentrations ranges from 0.007 to $0.05 \mathrm{mgP} / \mathrm{l}$, however, the total nitrogen concentration is much higher (10-14 mgN/l). The dissolved organic carbon (DOC) range from a minimum of $2.3 \mathrm{mgC} / \mathrm{l}$ to a maximum of $4.1 \mathrm{mgC} / \mathrm{l}$. Colgada Lake has a water conductivity varying from 591 to $713 \mu \mathrm{S} / \mathrm{cm}, \mathrm{pH}$ values of 7.3-8.2, and dissolved oxygen concentrations of $8.5-13.5 \mathrm{mg} / \mathrm{l}$. The waters are quite transparent and Secchi depth oscillates between 4 and $9 \mathrm{~m}$, depending on the season. Álvarez-Cobelas et al. (2006 a and b) may be consulted for a more detailed description of the physical, chemical and hydrological characteristics of the lake.

\section{Sampling and sample analyses}

Sampling was performed monthly from June 2003 to December 2004, covering two thermal stratification periods and two mixing ones. The 
sampling station was located at the central part of the lake with a maximum depth of $15 \mathrm{~m}$.

Water samples were taken with a limnological bottle (Niskin) at every metre of depth. When the water column was thermally stratified, an integrated sample was composed of the samples taken at every metre, for each one of the different water layers (epilimnion, metalimnion, and hypolimnion -which was not anoxic-). During the months when the water column remained mixed, a unique integrated sample was prepared with the samples taken at each metre of depth. Aliquots from the integrated samples were separated, their volumes dependent upon the kind of organism to be analysed. Samples for phytoplankton and ciliates were kept in $250 \mathrm{ml}$ bottles and immediately fixed with Lugol solution $50 \mathrm{ml}$ bottles were used for the samples dedicated to the determination of bacterioplankton, autotrophic picoplankton (APP) and heterotrophic nanoflagellates (HNF) and were immediately fixed with formalin at a final concentration of $1-2 \%$. Samples for metazooplankton determination (10 litres) were filtered through a $45 \mu \mathrm{m}$ Nytal mesh and fixed in situ with formalin-glucose $4 \%$ solution (Haney $\&$ Hall, 1973). All samples were kept in the dark until the determination studies.

For phytoplankton and ciliate determination, water samples were sedimented in Utermöhl chambers, and identification and counting of the different populations were later performed with an Olympus CK2 inverted microscope at $400 \mathrm{X}$ and $1000 \mathrm{X}$. At least 500 individuals were counted and 10 individuals measured for each population in order to determine the size. Cell volume was calculated using geometric form formula (Rott, 1981).

Identification and counting of metazooplankton was made in sedimentation chambers and the samples were observed by means of an inverted microscope. The zooplankton fresh weight was determined from body biovolumes, a geometric figure being assigned for each species (McCauley, 1984).

For the bacterioplankton and HNF counts, water samples were filtered through $0.2 \mu \mathrm{m}$ pore diameter Nucleopore black filters and stained by the acridine orange method of Hobbie et al.
(1977). Samples for APP determination were filtered through the same kind of filters and the counts were made by the autofluorescence observation of picoplanktonic cells (Weisse, 1988). For the bacterioplankton, HNF and the APP, a Nikon epifluorescence microscope was used at $1000 \mathrm{x}$ magnification and with the appropriate filters. Dimensions of several cells were measured from photographs taken of the preparations and the picoplancton cell biovolumen was calculated using appropriated geometric form formula (mainly spheric).

The ciliate taxonomical identification was made based on Foissner et al. (1999), and that for phytoplankton and metazooplankton as described in Álvarez-Cobelas et al. (2006a).

The carbon content for the different planktonic groups was estimated. For phytoplankton, the conversion of overall algal biovolume to carbon of Rocha \& Duncan (1985) was used: $\mathrm{pgC}=0.11$ $\times\left(\mu \mathrm{m}^{3}\right)$, for ciliates that cited in Menden-Deuer $\&$ Lessard (2000): $\operatorname{pgC}=0.22 \times\left(\mu \mathrm{m}^{3}\right)^{0.939}$, for bacterioplankton and APP the conversion proposed by Bratbak \& Dundas (1984): $\mathrm{pgC}=0.22 \times$ $\left(\mu \mathrm{m}^{3}\right)$. In the case of rotifers and crustaceans, dry weight (DW) was used for the conversion to carbon: $\mathrm{pgC}=0.5 \times(\mathrm{DW}, \mathrm{pg})($ Latja \& Salonen, 1978).

\section{RESULTS}

\section{Composition and abundance}

\section{Phytoplankton}

Sixty-two species of phytoplankton were identified, ten belonging to Cyanobacteria (Cyanophyceae), six to Cryptophyceae, six to $\mathrm{Di}$ nophyceae, eight to Chrysophyceae, twenty four to Chlorophyta, five to Bacillariophyceae, and three to Conjugatophyceae (Desmidiales). Minimum densities were found in April 2004 when the water column was mixed $(8.5 \times$ $10^{2}$ cells $/ \mathrm{ml}$ ), while the maximum density of $1.6 \times 10^{4} \mathrm{cells} / \mathrm{ml}$ was measured in August 2003, when the lake was thermally stratified and Cyclotella ocellata dominated.

The non-colonial, small, central diatoms $(C y$ clotella meneghiniana and Cyclotella ocellata), 
the Cryptophyceae Cryptomonas erosa, and the Dinophyceae Ceratium hyrundinella were present throughout the year and contributed significantly to the overall biomass. These algae, together with the Dinophyceae Peridinium willei, are responsible for almost all the biomass present during both the stratification period and the start of the 2003 mixing period. In winter, colonial Cyanobacteria, such as Microcystis botris appeared, while Peridinium willei disappeared, being substituted by others of a smaller size, such as Gymnodinium helveticum or Peridinium umbonatum. During spring 2004 the massive presence of dinoflagellates, especially the return of Peridinium willei, and the appearance of filamentous and colonial Cyanobacteria, such as Planktothrix agardhii and Microcystis botris, were the most remarkable facts in terms of algal composition. The thermal stratification of 2004 differed from that of 2003 in algal composition, due to the presence of these large-sized Cyanobacteria. During the autumnal mixing, small dinoflagellates were not observed, but only Ceratium hyrundinella and Peridinium willei, together with colonial Cyanobacteria, Cyclotella, and Cryptomonas spp., representing the small cell class, remained in high densities.

\section{Metazooplankton}

Nineteen species of Rotifers and 6 species of Cladocerans were identified. Cyclopoida and Calanoida copepods were also observed. The minimum metazooplankton density was 6 ind/l in December 2003 and the maximum was $279 \mathrm{ind} / \mathrm{l}$ in April 2004 (dominance of Keratella cochlearis). During the 2003 stratification and the start of the autumnal mixing, the main species noted were the cladocerans Ceriodaphnia quadrangula and Sida crystallina. The rotifers Asplachna sp. and Trichocerca sp., and the copepods Tropocyclops prasinus and Eudiaptomus sp. were dominant. In winter, cladocerans began to disappear, with the exception of a single peak of Daphnia longispina. Among rotifers, a change was also observed, namely, Keratella cochlearis and Keratella quadrata were then the most abundant species while copepods continued to be represented by a calanoid species. In spring 2004 Tropocyclops prasinus appeared once more and remained until the summer, the calanoid species disappeared from that time to the end of the study period. Ceriodaphnia quadrangula and the rotifer Asplachna sp. reappeared once again. The stratification and mixing periods of 2004 were different from those of 2003, precisely in the metazooplankton composition, due to the continuous and massive presence of the cyclopoid copepod together with the cladocerans.

\section{Bacterioplankton, APP, HNF and ciliates}

The lowest density of bacterioplankton was observed in October $2003\left(5.4 \times 10^{4}\right.$ cells $\left./ \mathrm{ml}\right)$ and the maximum density in September 2004 $\left(72.2 \times 10^{4}\right.$ cells $\left./ \mathrm{ml}\right)$. APP in Colgada Lake was constituted by cocal Cyanobacteria rich in phycocyanine, of about $1 \mu \mathrm{m}$ in diameter. Minimum APP density was $3.9 \times 10^{2}$ cells $/ \mathrm{ml}$ (June 2003) and the maximum was $1.6 \times 10^{5}$ cells/ml (July 2004). HNF were undetected in sedimented samples in Utermöhl chambers for phytoplankton observation at $1000 x$, in acridine orange stained samples, nor in samples observed through autofluorescence.

The ciliate community was formed by 12 species: four belonging to Oligotrichida ( Limnostrombidium pelagicum, Rimostrombidium lacustris, Rimostrombidium velox, and Codonella cratera), one to Peritrichida (Pelagovorticella sp.), five to Gymnostomatea (Monodinium sp, Monodinium perrieri, Belonophrya pelagica, Pelagovasicola cinctum, and Lagynophrya acuminata), one to Colpodea (Cyrtolophosis bivacuolata), and one to Prostomatida (Urotricha sp). The ciliate species ranged from 18 to $52 \mu \mathrm{m}$ in length and were bacterivore and herbivore-bacterivore species (Foissner et al., 1999). The lowest ciliate density was found in August $2003(0.2$ cells $/ \mathrm{ml})$ and the highest in October of the same year $(6.8$ cells $/ \mathrm{ml})$.

\section{Planktonic dynamics}

Figure 1A represents phytoplankton integrated biomass dynamics in the water column 

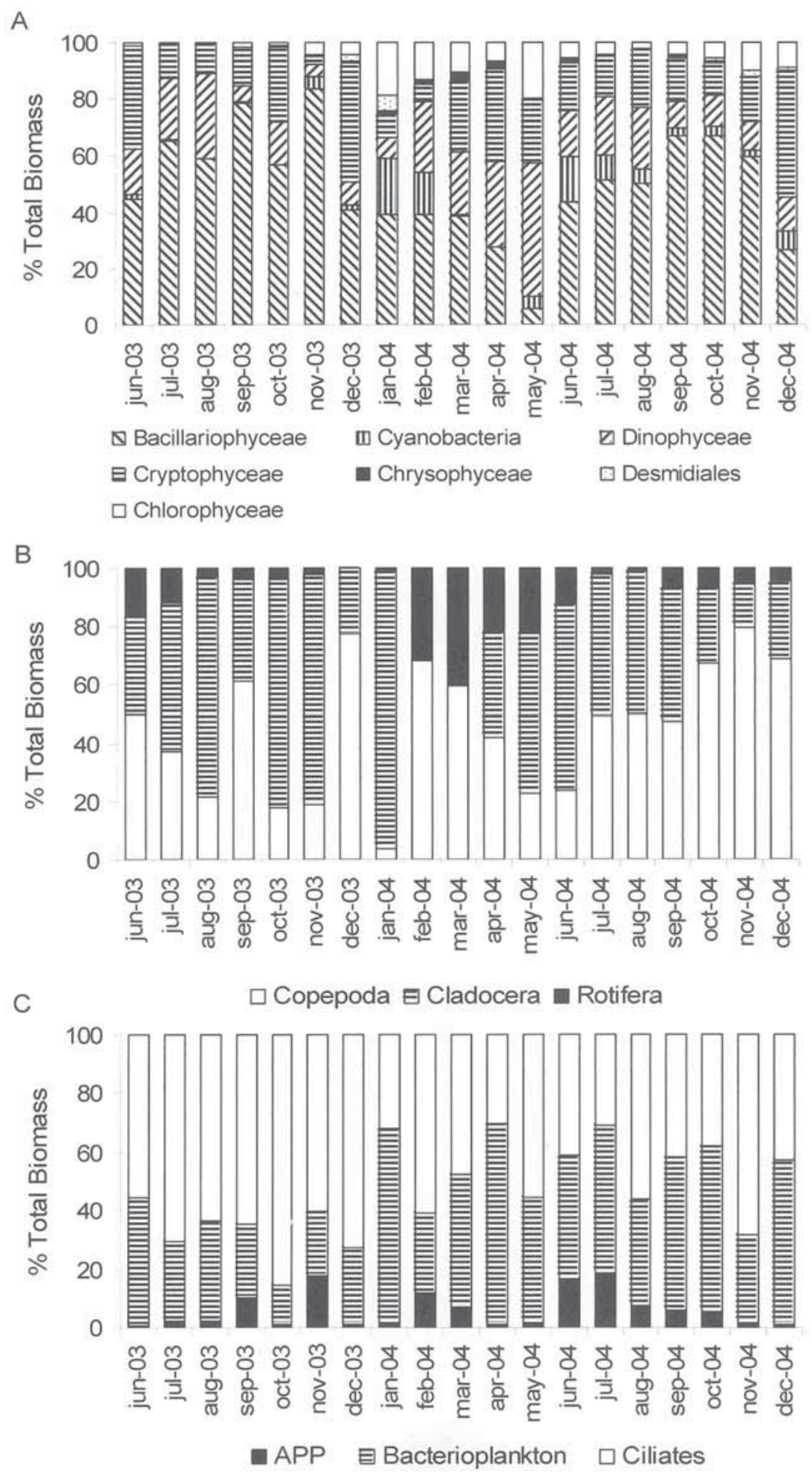

Figure 1. Integrated biomass dynamics in the water column of the different planktonic groups of Colgada Lake. Dinámica de la biomasa integrada en la columna de agua de los distintos grupos planctónicos en la Laguna Colgada. 
Plankton dynamics of one of the Ruidera Lakes
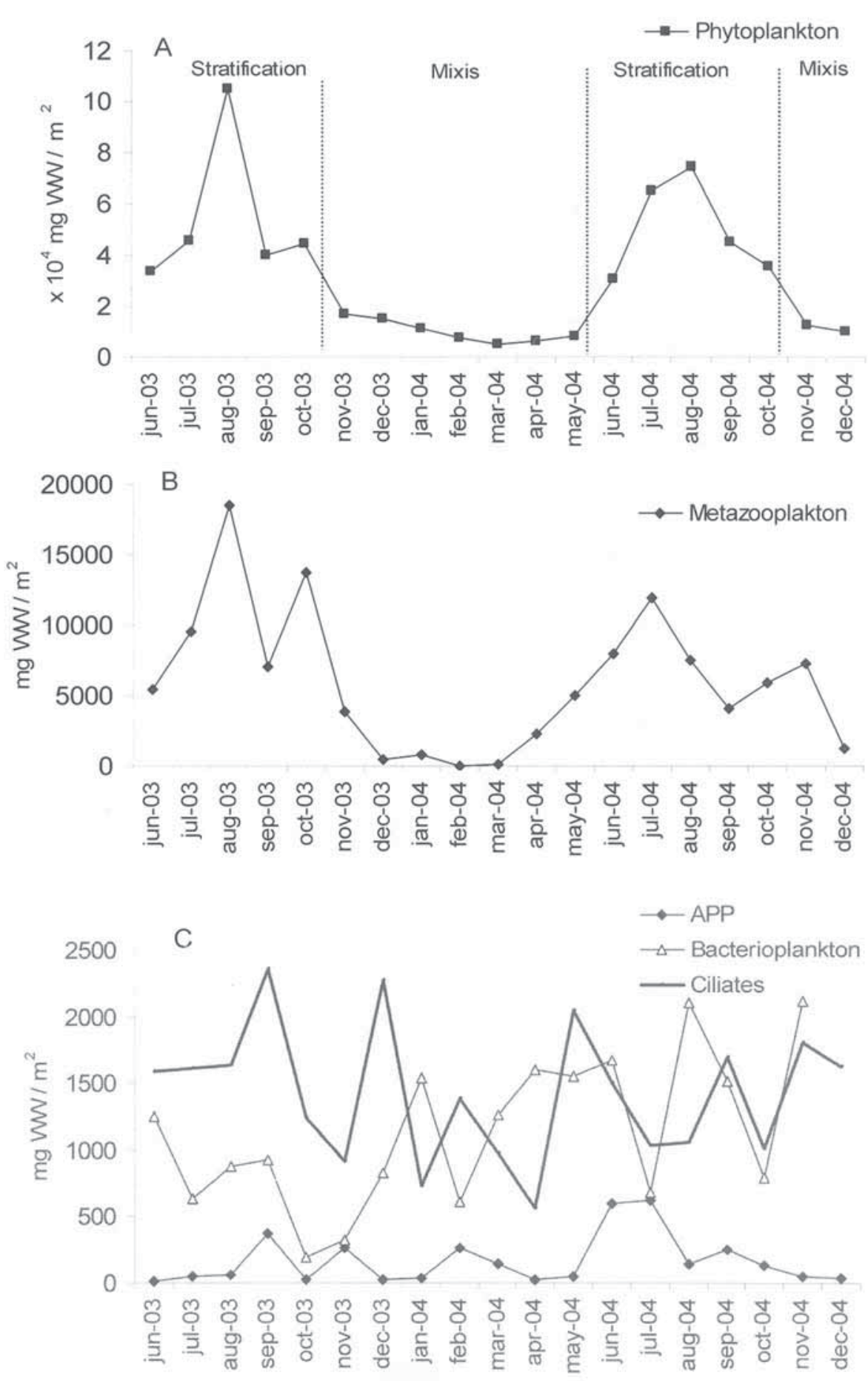

Figure 2. A. Contribution of different taxonomic groups to total phytoplankton biomass. B. Rotifer and crustacean contribution to the total metazooplankton biomass. C. Contribution of picoplankton and protozoans (ciliates) to the total microbial loop biomass. $\boldsymbol{A}$. Contribución de los diferentes grupos taxonómicos al total de la biomasa del fitoplancton. B. Contribución de rotíferos y crustáceos al total de la biomasa del metazooplancton. C. Contribución del picoplancton y los protozoos (ciliados) a la biomasa total del bucle microbiano. 
throughout the study period. An evident seasonal pattern can be observed with two distinct biomass peaks during the summers of 2003 and 2004. The dominance of diatoms can be observed in figure $2 \mathrm{~A}$, with increases during both summers.

The metazooplankton integrated biomass also follows a seasonal dynamic, showing higher values during both summers (Fig. 1B). The percentage contribution for each group to total biomass (Fig. 2B) varied dependent upon the season. Cladocerans dominated during summer and autumn 2003, while copepods and rotifers dominated in winter. Cladocerans and copepods dominated during spring and summer 2004, whereas copepods were prevalent in autumn and winter 2004.

The integrated biomass dynamics of APP, bacterioplankton and ciliates had different trajectories (Fig. 1C). APP showed the highest biomass values in summer 2004, bacterioplankton showed no differences when comparing seasons, but an increase in population growth was observed in the second year. Ciliate biomass dynamics showed neither intra-annual nor interannual differences. Ciliates were the main compartment of the microbial loop (Fig. 2C) until

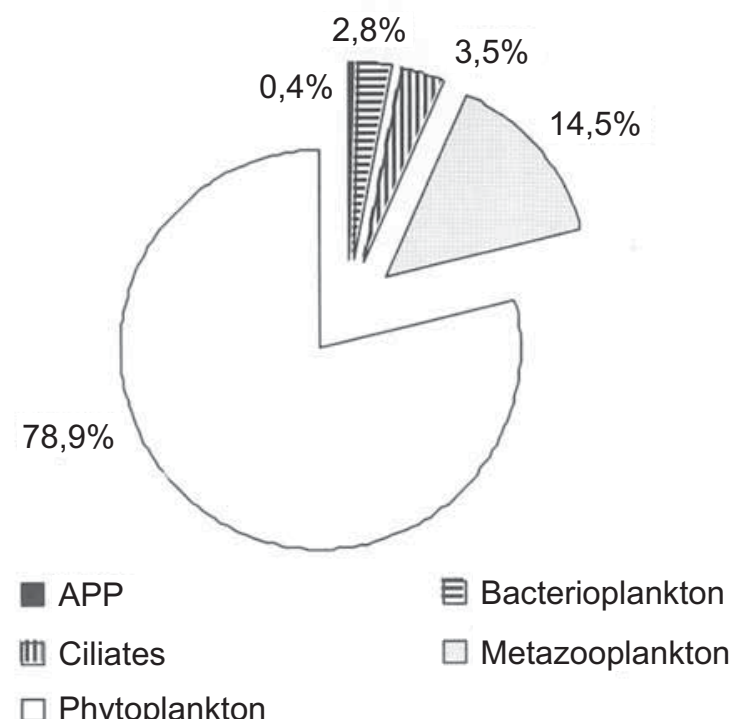

Figure 3. Annual mean percentage of integrated biomass represented by each planktonic group $\left(\mathrm{mgWW} / \mathrm{m}^{2}\right)$ in Colgada Lake. Porcentaje promedio anual de la biomasa integrada $\left(\mathrm{mgPF} / \mathrm{m}^{2}\right)$ que representan cada uno de los grupos planctónicos en la laguna Colgada.
December 2003 (55-85 \%) and bacterioplankton was dominant in the thermal stratification of 2004 (37-52\%). APP did not exceed $18 \%$ during the study period (Fig. 2C).

Considering the overall planktonic biomass (annual mean percentage of integrated biomass in the water column, Fig. 3), phytoplankton represented the highest biomass (nearly $80 \%$ ) of this food web, whereas zooplankton only constituted $15 \%$. The ciliate, APP and bacterioplankton biomass representation was low, being less than $7 \%$. In terms of carbon (Fig. 4A), the highest concentration was allocated in the lineal phytoplankton-metazooplankton chain (APP and rotifers being less relevant) and

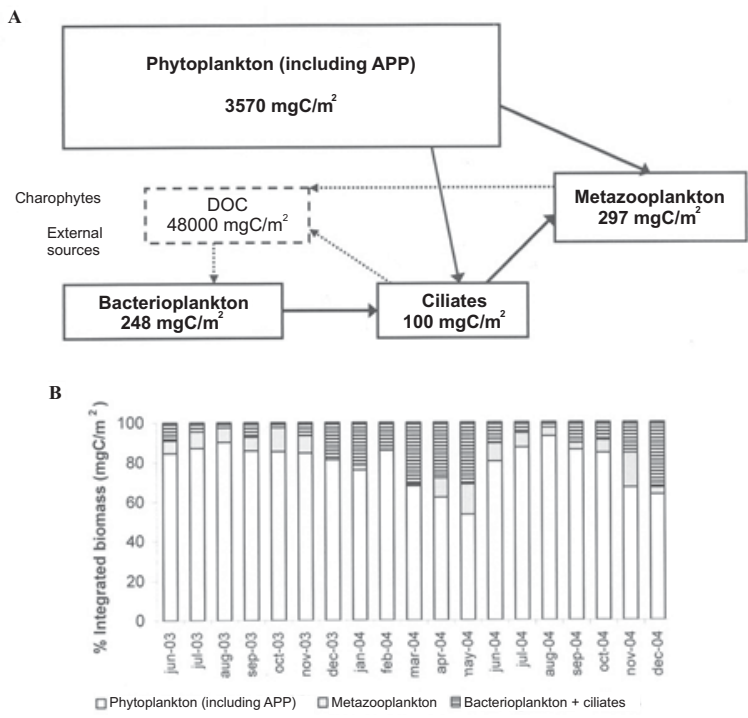

Figure 4. A. Scheme of the planktonic food web, including the microbial loop in Colgada Lake. The square areas are almost proportional to the biomass of each planktonic group. Solid arrows indicate trophic relationships and dashed ones indicate dissolved organic carbon (DOC) sources. Values are averages of the biomass of different plankton compartments integrated in the water column $(0-15 \mathrm{~m}) \mathbf{B}$. Temporal variation of the percentage of the integrated average biomass of the different components of the planktonic food web. $\boldsymbol{A}$. Esquema de la red trófica planctónica, incluyendo el bucle microbiano en la laguna Colgada. El área de los cuadrados es prácticamente proporcional a la biomasa de cada uno de los grupos planctónicos. Las flechas continuas indican las relaciones tróficas, las discontinuas indican las fuentes de carbono orgánico disuelto (DOC). Los valores son promedios de las biomasas de los diferentes compartimientos planctónicos integrados en la columna de agua $(0-15 \mathrm{~m})$. B. Variación temporal del porcentaje de la biomasa integrada de los diferentes componentes de la red trófica planctónica. 
a lower fraction was allocated in the microbial loop components. However, during the winter mixing period, the relative contribution of the microbial loop was higher (Fig. 4B).

\section{DISCUSSION}

The Ruidera Lakes system is hydrogeologically comparable only to the Plitvice lakes (Croacia) and the cascade lakes of Zlatokopy (Czech Republic). Therefore, although latitude and climate are different, it is not strange that Colgada Lake (central lake in the Ruidera system) has a microalgae flora similar to the ones described for such environments (Krmpotić, 1913; Punčochářová-Nováková \& Punčochář; 1976; Álvarez-Cobelas et al., 2006a). The phytoplankton abundance dynamics are clearly seasonal, typical of temperate lakes, with peaks in summer, reaching values that are indicative of eutrophic conditions (Willén, 2000) and the worse water quality since 2000 (Bort, 2005). In the two years of this study, no clear annual trend in phytoplankton abundance was observed, but there was a change in algal composition, demonstrating once more, that total algal biomass is the most conservative variable in the planktonic community (Rojo et al., 2000; Sommer et al., 2002). Although the biomass distribution in diatoms, Cryptophyceae and Dinophyceae is the most recognizable pattern, the increase in colonial Cyanobacteria (Microcystis) indicates an impoverishment of water quality (Reynolds, 1998). The presence of small, centric diatoms from spring onwards may be considered as an indicator of functional group A-B (Reynolds et al., 2002) while the presence of Peridinium and Ceratium species (together with Microcystis) during the thermal stratification period indicates the functional group $\mathrm{L}\left(\mathrm{L}_{O}-\mathrm{L}_{M}\right)$, typical of meso-eutrophic lakes. However, this seasonal progression does not occur in Colgada Lake, since these algae are found throughout the year, being mobile dinoflagellates dominant even during the mixing period. An increment in the bacterioplankton and APP biomass was also observed, and at the same time the larger algae (Ceratium, Microcystis) biomass also increased. In this way, the intermediate size algae, suitable for a higher efficacy of cladocerans and copepods, decreased.

Zooplankton in Colgada Lake also follows a seasonal pattern, being more abundant in summer than in winter, a typical pattern for temperate lakes. Rotifers reach the highest biomass percentages at the end of winter and at the beginning of spring. Cladocerans and calanoid copepods are more relevant in spring and summer while cyclopoid copepods are the main biomass contributors in winter. This sequence is similar to that described as the seasonal pattern for temperate lakes (PEG model, Sommer et al., 1986). However, an inter-annual variation was observed, with the substitution of cladocerans and herbivorous calanoids by omnivorous cyclopoids in summer and autumn. This suggests an increase in the number of copepod generations, as has already been observed in relation to climate change (Gerten \& Adrian, 2002) and on the other hand, the substitution of cladocerans by copepods, since a change in diet occurred due to the increase of larger algae (Sommer \& Sommer, 2006). This substitution also coincides with the higher relevance of the microbial loop components (Wetzel, 2001): bacteria will be favoured by the regeneration of phosphorus, due to the copepod activity. At the same time, the copepod population can predate on protozoans (Vrede \& Vrede, 2005; Álvarez-Cobelas et al., 2006) and small rotifers, thus increasing the fraction of smaller primary producers (Stibor et al., 2004).

Whereas in other lakes, HNF predominate in the protozoan community (Pirlot et al., 2005), ciliates are more abundant than HNF in Colgada Lake, the latter being practically undetectable. Ciliate density found in Colgada Lake is similar to that found in oligotrophic lakes, according to the classification of Beaver \& Crisman (1989). In fact, the ciliate biomass found in Colgada Lake was lower than that found in the mesotrophic Lake Constanza (Cleven, 2004). However, in Colgada Lake we found a high diversity of ciliates, similar to that of this German lake (Cleven, 2004). Ciliate biomass was sustained by 
bacterioplankton, APP, and other small algae like Cryptomonas or Cyclotella species (the latter can serve as food for larger volume ciliates; Weisse \& Müller, 1998). This is for example the case of the Rimostrombidium genus, whose preference for this kind of algae has been described, and only during periods of low phytoplankton biomass is bacterioplankton used to complete the diet (Cleven, 2004). Such a case would correspond to a winter period in Colgada Lake, when phytoplankton is drastically reduced but levels of bacterioplankton biomass remain high. On the other hand, dissolved organic carbon concentrations (DOC) in Colgada Lake waters are not low. Their origin is due not only to the excretion products of phytoplankton and zooplankton (Pirlot et al., 2005) but is also caused by the large biomass of charophytes developed in this lake (Sosnovsky et al., 2005; Rodrigo et al., 2007), and by allocthonous sources as well. In spite of the DOC water concentrations, the bacterial biomass is not very high, since there is possibly a top-down control due to ciliate predatory action.

APP is also a source of food for many microherbivores, such as ciliates (Weisse, 1988), and also for rotifers and some cladocerans (Stockner $e t$ $a l ., 2000)$. Alternatively, APP growth rates were similar to those of heterotrophic bacterioplankton. In this way, APP may be regarded as an important microbial food web component in many aquatic ecosystems (Sommaruga \& Robarts, 1997). In Colgada Lake, APP biomass is not very high, especially when compared to bacterioplankton biomass; however, in some moments during the annual cycle, APP may represent a considerable food supply for consumer trophic levels.

In terms of biomass, the prevalence of a lineal food chain on the microbial loop is clear in Colgada Lake (Fig. 4). Yet, it is remarkable that during the mixing period, the contribution of microbial loop components to energy and matter transfer in the food web can be as high as it is in this lake.

We could summarise the dynamics of the food web in this monomictic and mesotrophic lake as a sequence of states that do not present a sharp inter-annual seasonality (Allen et al., 1977; Rojo et al., 2000), and where the microbial loop gains relevance at certain times. From the end of spring through to summer, a relevant presence of small-sized diatoms was observed, together with Cryptophyceae and Dinophyceae, accompanied by an increment of herbivore metazooplankton (cladocerans and calanoids) biomass and the presence of ciliates as an important part of the microbial loop. In autumn, coinciding with the vertical mixing of the water column, a high variability was observed in algal composition, in large-sized herbivores and the smaller components of the microbial loop, such as occurs in other temperate lakes with autumnal overturn (Álvarez-Cobelas et al., 2006c). During this autumnal overturn, cyclopoid copepods and rotifers dominate, this being the moment when a high biomass of non-edible algae by herbivores occurs and when the link between microbial loop and lineal chain, whose top species is the carnivorous Tropocyclops, is clearly observed (Fig. 4). During the subsequent spring, the large herbivores appear; substituting the rotifers, while the predator Tropocyclops remains and its relative presence becomes higher each time and is uninterrupted until winter. Since there are few rotifers and less cladocerans each time, the presence of this predator must be linked to the microbial loop.

The changes observed are in part due to the eutrophication process from which Colgada Lake has suffered from during the last few years. For a considerable time, high concentrations of nitrate (due to agriculture activities) were detected, but lately, increases in phosphorus concentrations have also been observed (Álvarez-Cobelas et al., 2006a). This fact establishes that algal composition can include larger and non-edible species and, consequently, there exists a reduction in the clearance rates of the cladocerans (Sommer et $a l .$, 1986). This circumstance could cause the lake's trophic state to change. If primary planktonic production is not controlled by herbivory, the annual re-growth of submerged charophytes which develop in this lake and help to maintain its good water quality would be affected (Scheffer et al., 1993; Rodrigo et al., 2007). 


\section{ACKNOWLEDGEMENTS}

The authors wish to thank the University of Valencia for the pre-doctoral grant (V Segles) to M. Mercedes Barón-Rodríguez. We also wish to acknowledge Ernesto Mangas for his collaboration with the zooplankton counts, together with the assistance of Miguel Álvarez-Cobelas (Instituto de Recursos Naturales, CSIC) and his research team, and to the project CGL2006-2346 (Spanish Ministry) thanks to which this project was completed.

\section{REFERENCES}

ALLEN T. F. H., S. M. BARTELL, J. F. KOONCE. 1977. Multiple stable configurations in ordination of phytoplankton community change rates. Ecology, 58: 1076-1084.

ÁlVAREZ-COBELAS M., S. CIRUJANO, E. MONTERO, C. ROJO, M. A. RODRIGO, E. PIÑA, J. C. RODRÍGUEZ MURILLO, O. SORIANO, M. ABOAL, J. P. MARÍN \& R. ARAUJO. 2006a. Aquatic ecology and society of Ruidera lakes (Central Spain). Madrid: Publicaciones CSIC. 414 pp.

ÁlVAREZ-COBELAS, M., S. CIRUJANO, C. ROJO, M. A. RODRIGO, E. PIÑA, J. C. RODRÍGUEZ-MURILLO \& E. MORENO. 2006b. Effects of changing rainfall on the limnology of a Mediaterranean, flowthrough-seepage Chain of lakes. Internat. Rev. Hydrobiol., 91: 466-482.

ÁlVAREZ-COBELAS, M., A. BALTANÁS, J. L. VELASCO \& C. ROJO. 2006c. Zooplankton dynamics during autumn circulation in a small, windsheltered, Mediterranean lake. Mar. Freshwater Res. 57: 441-452.

ARMENGOL, J., M. ESTRADA, A. GUISET, R. MARGALEF, D. PLANAS, J. TOJA y F. VALLESPINÓS. 1975. Observaciones limnológicas en las lagunas de La Mancha. Bol. Est. Central. Ecol., 4: 11-27.

AZAM, F., T. FENCHEL, J. G. FIELD, J. S. GRAY, L. A. MEYER-REIL \& F. THINGSTAD. 1983. The Ecological Role of Water-Column Microbes in the Sea. Mar. Ecol. Progr. Ser., 10: 257-263.

BEAVER, J. R. \& T. L. CRISMAN. 1989. The role of ciliates protozoa in pelagic freshwater ecosystems. Microb. Ecol., 17: 111-136.
BORT, S., C. ROJO, M. A. RODRIGO \& N. MAIDANA. 2005. El fitoplancton de las Lagunas de Ruidera (Parque Natural, Ciudad Real, España). Limnetica, 24: 33-46.

BRATBAK, G. \& I. DUNDAS. 1984. Bacterial dry matter content and biomass estimations. Appl. Environ. Microbiol., 48: 755-757.

CARPENTER, S. R., J. J. COLE\& J. R. HODGSON. 2001. Trophic cascades, nutrients, and lake productivity: whole-lake experiments. Ecol. Monogr., 71: 163-186.

CLEVEN E. J. 2004. Pelagic ciliates in a large mesotrophic lake: Seasonal sucession and taxonspecific bacterivory in Lake Constance. Internat. Rev. Hydrobiol., 89: 289-304.

COTTINGHAM, K. L. 1999. Nutrients and zooplankton as multiple stressors of phytoplankton communities: Evidence from size structure, Limnol. Oceanogr., 44: 810-827.

DE EYTO, E. \& K. IRVINE. 2005. Variation in the biomass of functional groups comprising the openwater plankton of shallow lakes in Ireland. Biology and Environment, 105B: 53-58.

ELSER, J. J., L. B. STABLER \& R. P. HASSETT. 1995. Nutrient limitation of bacterial growth and rates of bacterivory in lakes and oceans: a comparative study. Aquat. Microb. Ecol., 9: 105110.

FOISSNER, W., H. BERGER, \& J. SCHAUMBURG. 1999. Identification and ecology of limnetic plankton ciliates. Munich: Bayerisches Landesamt für Wasserwirtschaft. 793 pp.

GERTEN, D. \& R. ADRIAN. 2002. Species-specific changes in the phenology and peak abundance of freshwater copepods in response to warm summers. Freshwater Biol., 47: 2163-2173.

GLIWICZ, Z. M. 1990. Food thresholds and body size in cladocerans. Nature, 343: 638-640.

JEPPESEN, E., M. SØNDERGAARD, J. P. JENSEN, E. MORTENSEN \& O. SORTKJAER. 1996. Fish-induced changes in zooplankton grazing on phytoplankton and bacterioplankton: a long-term study in shallow hypertrophic Lake Søbygaard. J. Plankton Res., 18: 1605-1625.

JOAQUIM-JUSTO, C., S. PIRLOT \& L. VIROUX. 2006. Trophic links in the lowland River Meuse (Belgium): assessing the role of bacteria and protozoans in planktonic food webs. J. Plankton Res., 28: 857-870. 
HANEY, J. \& D. HALL. 1973. Sugar-coated Daphnia: a preservation technique for cladocera. Limnol. Oceanogr., 18: 331-333.

HÅKANSON, L. \& R. H. PETERS. 1995. Predictive Limnology. SPB Academic Publishing 464 pp.

HOBBIE, J., R. DALEY, \& S. JASPER. 1977. Use of Nucleopore filters for counting bacteria by fluorescence microscopy. Appl. Environ. Microbiol., 33: 1225-1228.

HUBER, V. \& U. GAEDKE. 2006. The role of predation for seasonal variability patterns among phytoplankton and ciliates. Oikos, 114: 265-276.

KITCHELL, J. F. \& S. R. CARPENTER. 1993. Cascading trophic interactions. In: The Trophic Cascade in Lakes. S.R. Carpenter \& J.F. Kitchell (eds):1-14. Cambridge University Press, Cambridge, England.

KRMPOTIĆ, I. N. 1913. Prilog mikrofauni Plitvičkih jezera [Contribución a la microfauna de los lagos de Plitvice]. Glasnik, 25: 1-29.

LATJA, R. \& K. SALONEN. 1978. Carbon analysis for the determination of individual biomass of planktonic animals. Int. Ver Theor. Angew. Limnol. Verh., 20: 2556-2560.

MENDEN-DEUER, S. \& E. LESSARD. 2000. Carbon to volume relationships for dinoflagellates, diatoms and other protist plankton. Limnol. Oceanogr., 45: 569-579.

MCCAULEY, E. 1984. The estimation of the abundance and biomass of zooplankton in samples. In: A Manual on Methods for the Assessment of Secondary Productivity in Fresh Waters, $2^{\text {nd }}$ ed. J.A. Dowing \& F.H. Rigler (eds): 228-265. Backwell Scientific Publications, Oxford, England.

MUYLAERT, K., L. ZHAO \& K. VAN DER GUCHT. 2006. Trophic coupling in the microbial food web of a eutrophic shallow lake (Lake Visvijver, Belgium). Arch. Hydrobiol., 166: 307-324.

NIQUIL, N., G. BARTOL \& J. URABE. 2006. Carbon steady-state model of the planktonic food web of Lake Biwa, Japan. Freshwater Biol., 51: 1570-1585.

OECD 1982. Eutrofication of Waters: Monitoring, assessment and control. Paris: OECD. 154 pp.

ORTEGA-MAYAGOITIA, E., C. ROJO \& J. ARMENGOL. 2000. Structure and dynamics of zooplankton in a semi-arid wetland, the National Park Las Tablas de Daimiel (Spain). Wetlands, 20: 629638.

PIRLOT, S., J. VANDERHEYDEN, J. P. DESCY \& P. SERVAISL. 2005. Abundance and biomass of heterotrophic microorganisms in Lake Tanganyika. Freshwater Biol., 50: 1219-1232.

POMEROY, L. R. 1974. The ocean's foodweb: a changing paradigm. BioScience, 24: 499-504.

POPOVSKÝ, J. \& L. A., PFIESTER. 1990. Dinophyceae. Süswasserflora von Mitteleuropa, 6. Stuttgart: Gustav Fischer Verlag. 272 pp.

PUNČOCHÁŘOVÁ-NOVÁKOVÁ, M. \& P. PUNČOCHÁŘ. 1976. Phytoplankton composition and chemical characteristics of water in a cascade of ponds and their inflow. Arch. Hydrobiol., Algologische Studien, 17: 450-471.

REYNOLDS, C. S. 1998. What factors influence the species composition of phytoplankton in lakes of different trophic status? Hydrobiologia, 370: 1126.

REYNOLDS, C. S., M. DOKULIL \& J. PADISÁK. 2000. Understanding the assembly of phytoplankton in relation to the trophic spectrum: where are we now? Hydrobiologia, 424:147-152.

REYNOLDS, C. S., V. HUSZAR, C. KRUK, L. NASELLI-FLORES \& S. MELO. 2002. Towards a functional classification of the freshwater phytoplankton. J. Plankton Res., 24: 417-428.

ROCHA, O. \& A. DUNCAN. 1985. The relationship between cell carbon and cell volume in freshwater algal species used in zooplanktonic studies. $J$. Plankton Res., 7: 279-294.

RODRIGO, M. A., C. ROJO \& M. ÁLVAREZ-COBELAS. 2003. Autotrophic and heterotrophic picoplancton in wetlands: differences with lake patterns. Internat. Rev. Hydrobiol., 88: 464-481.

RODRIGO, M. A., C. ROJO, M. ÁlVAREZ-COBELAS \& S. CIRUJANO. 2007. Chara hispida beds as a sink of nitrogen: evidence from growth, nitrogen uptake and decomposition. Aquat. Bot. (doi.org/10.1016/j.aquabot.2007.01.007).

ROJO, C. 1998. Differential attributes of phytoplankton across the trophic gradient: a conceptual landscape with gaps. Hydrobiologia, 360/370: 1-9.

ROJO, C., E., ORTEGA-MAYAGOITIA, M. A., RODRIGO \& M. ÁLVAREZ-COBELAS. 2000. Phytoplankton structure and dynamics in a semiarid wetland, the National Park Las Tablas de Daimiel (Spain). Arch. Hydrobiol., 148:397-419.

ROTT, E. 1981. Some results from phytoplankton counting intercalibrations. Schweiz. Z. Hydrol., 43, 34-62.

SCHEFFER, M., S. H. HOSPER \& M. L. MEIJER. 1993. Alternative equilibria in shallow lakes. Trends Ecol. Evol., 8: 275-279. 
SHERR, E. B., B. F. SHERR \& T. BERMAN. 1991. High abundance of picoplankton-ingesting ciliates during late fall in lake Kinneret, Israel. J. Plankton Res., 13: 789-799.

SHERR, E. B. \& B. F. SHERR. 2002. Significance of predation by protists in aquatic microbial foodwebs. Anton. Leeuw. Int J.G., 81: 293-308.

SOMMARUGA, R. \& R. D. ROBARTS. 1997. The significance of autotrophic and heterotrophic picoplankton in hypertrophic ecosystems. FEMS Microbiol. Ecol., 24:187-200.

SOMMER, U., Z. M. GLIWICZ, W. LAMPERT \& A. DUNCAN. 1986. The PEG-model of seasonal succession of planktonic events in fresh waters. Arch. Hydrobiol., 106: 433-471.

SOMMER, U., H. STIBOR, A. KATECHAKIS, F. SOMMER \& T. HANSEN. 2002. Pelagic food web configurations at different levels of nutrient richness and their implications for the ratio fish production: primary production. Hydrobiologia, 484: 11-20.

SOMMER, U. \& F. SOMMER. 2006. Cladocerans versus copepods: the cause of contrasting topdown controls on freshwater and marine phytoplankton. Oecologia, 147: 183-194.

SOSNOVSKY, A., S. CIRUJANO, M. ÁLVAREZCOBELAS, M. MORENO \& E. PIÑA. 2005. Efectos antrópicos sobre praderas sumergidas de carófitos en una laguna cárstica. Anales del Real Jardín Botánico de Madrid, 62: 47-52.

STIBOR, H., O. VADSTEIN, S. DIEHL, A. GELZLEICHTER, T. HANSEN, F. HANTZSCHE, A. KATECHAKIS, B. LIPPERT, K. LØSETH, C. PETERS, W. ROEDERER, M. SANDOW, L. SUNDT-HANSEN \& Y. OLSEN.2004.Copepods act as a switch between alternative trophic cascades in marine pelagic food webs. Ecol. Lett., 7: 321-328.
STOCKNER, J. G. 1991. Autotrophic picoplancton in freshwater ecosystems: The view from the summit. Int. Revue ges. Hydrobiol., 76: 483-492.

STOCKNER, J., C. CALLIERI \& G. CRONBERG. 2000. Picoplankton and other non-bloom forming cyanobacteria in lakes. In: Ecology of cyanobacteria. Their Diversity in Time and Space. B.A. Whitton \& M. Potts (eds.): 195-231. Kluwer Academic Publishers, Netherlands.

VITOUSEK, P. M., J. D. ABER, R. W. HOWARTH, G. E. LIKENS, P. A. MATSON, D. W. SCHINDLER, W. H. SCHLESINGER \& D. G. TILMAN. 1997. Human alteration of the global nitrogen cycle: Sources and consequences. Ecol. Applic., 7: 737-750.

VREDE, T. \& K. VREDE. 2005. Contrasting "topdown" effects of crustacean zooplankton grazing on bacteria and phytoflagellates. Aquat. Ecol., 39: 283-293.

WEISSE, T. 1988. Dynamics of autotrophic picoplankton in Lake Constance. J. Plankton Res., 10: 1179-1188.

WEISSE, T. \& H. MÜLLER. 1998. Planktonic protozoa and the microbial foodweb in Lake Constante. Arch. Hydrobiol. Spec. Sigues Advanc Limnol., 53: 223-254.

WEISSE, T., H. MULLER, R. M. PINTOCOELHO, A. SCHWEIZER, D. SPRINGMANN \& G. BALDRINGER. 2000. Response of the microbial loop to the phytoplankton spring bloom in a large prealpine lake. Limnol. Oceanogr., 35: 781-794.

WETZEL, R. G. 2001. Limnology, $3^{\text {rd }}$ ed. San Diego: Academic Press. 1006 pp.

WILLÉN, E. 2000. Phytoplankton water quality assessment-an indicador concept. In: Hydrological and Limnological aspects of lake monitoring. Heinonen, P., G. Ziglio \& A. Van der Beken (eds): 5880. John Wiley \& Sons 1td., Chichester, England. 